
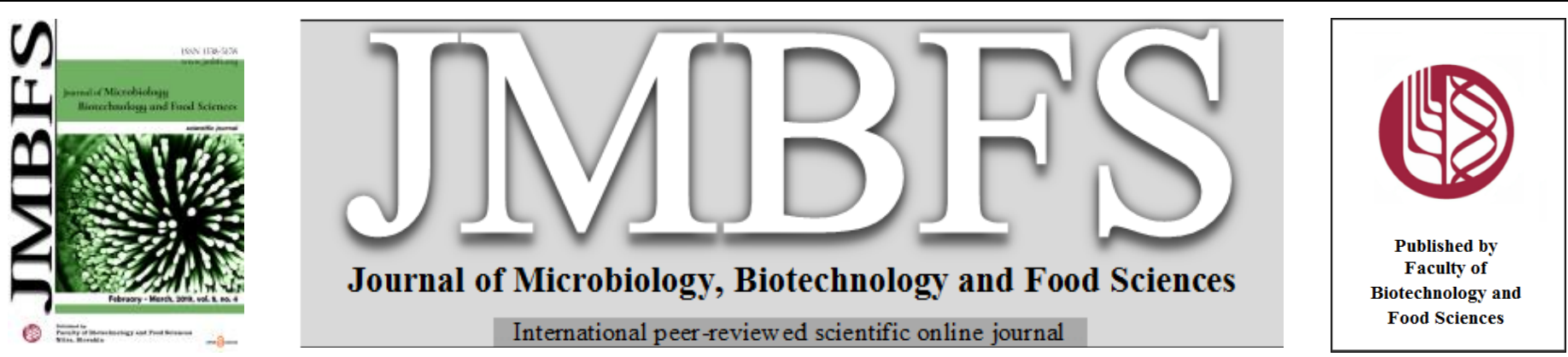

\title{
ASSOCIATIVE TO TRITICUM AESTIVUM L. BACTERIA AS A SOURCE OF STRAINS FOR BIOTECHNOLOGY OF THE RHIZOSPHERE
}

\author{
Tatyana Melnichuk, Anna Egovtseva, Suleiman Abdurashytov*, Elvina Abdurashytova, Irina Kameneva, Alla Yakubovskaya, \\ Aleksandr Radchenko, Tatyana Ganotskaya, Lyudmila Radchenko
}

Address(es): PhD Suleiman Abdurashytov,

FSBSI "Research Institute of Agriculture of Crimea", Kievskaya str., 150, 295493, Simferopol, Republic of Crimea, phone number:83652-56-00-07.

*Corresponding author: asuleyman83@ rambler.ru

doi: 10.15414/jmbfs.2019.8.5.1194-1197

\section{ARTICLE INFO}

Received 8. 6. 2018

Revised 10. 1. 2019

Accepted 10. 1. 2019

Published 1. 4. 2019

Regular article

open $\mathcal{O}$ access

\begin{abstract}
Associative microorganisms live in the zone of direct influence of plants namely in the soil, which is in close contact with the roots. They form complex communities on the roots of plants in terms of taxonomic composition and structural and functional o8rganization, which have polyfunctional effect on plants. Rhizosphere biotechnologies with the use of associative bacteria to a specific plant species allow increasing their productivity and quality, which contributes to the stability of agroecosystems. Therefore, the main goal of the current study was to isolate associative to Triticum aestivum L. bacteria from the southern chernozem (Haplic Chernozems), which was sampled in the steppe zone of the Crimea. The methodical approach was used to select associative microorganisms for a specific plant species. The number of microorganisms of the main ecological-trophic groups for three varieties T. aestivum were determined. The maximum number of rhizosphere microorganisms was identified for the Ermak variety, as well as the number of morphotypes isolated from the apical part of the root. As a result of the research, six strains of associative bacteria were obtained. They increased the seed quality of the studied varieties by $5 \%$ and the biomass of the seedlings by $80 \%$. Identification by the $16 \mathrm{~S}$ rRNA gene showed their belonging to different bacterial genera. Thus, the quantitative composition of the chernozem southern of the rhizosphere of three varieties of $T$. aestivum was determined. Five strains of associative bacteria promising for further biotechnology of the agrocenosis rhizosphere were isolated.
\end{abstract}

Keywords: associative bacteria, rhizosphere, Triticum aestivum $L$.

\section{INTRODUCTION}

The life cycle of plants passes closely with microorganisms. Associative microorganisms live in the zone of direct influence of plants namely in the soil, which is in close contact with the roots. They form complex communities on the roots of plants in terms of taxonomic composition and structural and functional organization, which have polyfunctional effect on plants (Sivasakthi et al., 2014; Souza et al., 2015; Artamonova et al., 2014).

Associative bacteria (PGPB- plant growth promoting bacteria) are naturally occurring soil bacteria that colonize plant roots and provides growth promotion and seeds germination either directly by solubilization phosphorus, potassium and zinc; by production indole acetic acids, gibberellic acid, cytokinin; phytohormones; biological nitrogen fixation or in-directly by production ammonia, hydrogen cyanide, siderophore and biocontrol against different plant pathogens (Dal Cortivo et al., 2017; Singh and Jha, 2016; Yadav et al., 2017).

Currently, there are many approaches to reducing plant stress, with particular attention to the use of growth stimulating associative rhizobacteria. Among the useful associations between plants and microorganisms, biological transformations of nitrogen are of great interest. This type of interaction is an important source of nitrogen and is a promising alternative to chemical nitrogen containing fertilizers. In addition to fixing nitrogen, these bacteria can also produce plant growth hormones, and some species improve nutrient intake and increase plant resistance to biotic and abiotic stresses (Shaposhnikov et al., 2011; Carvalho et al., 2014).

The use of microorganisms to improve the availability of nutrients for plants is an important practice and is necessary for sustainable agriculture (Yadav $\boldsymbol{e t}$ al. 2017). At the same time, for every species and even plant variety, it is necessary to select the strain that is the perfect match to the biological features of the plant organism, especially to the specificity of the root secretions determining the survival of the strain in the rhizosphere (Lebedev, 2014). Rhizosphere biotechnologies with the use of associative bacteria to a specific plant species allow increasing their productive potential and quality, which contributes to the stability of agroecosystems (Jha et al., 2013, Huang et al., 2014).
This study is aimed at studying associative to Triticum aestivum L. bacteria from the chernozem southern, which was sampled in the steppe zone of the Crimea.

\section{MATERIALS AND METHODS}

Plants

Three varieties of Triticum aestivum $\mathrm{L}$. were used in the experiments

1. Lydia; the originator - is Agricultural Research Centre "Donskoy" (Zernograd, Russia). It is the middle-early variety high resistant to lodging; highly productive; resistant to attack by brown rust and Smut (fungus); increased level of drought and frost resistance.

2. Bagheera; the originator - is Stavropol Research Institute of Agriculture (Mikhaylovsk, Russia). It is resistant to attack by brown rust and powdery mildew; moderately stable to Septoria; medium-resistant to drought, frost and lodging.

3. Ermak; the originator - is Agricultural Research Centre "Donskoy" (Zernograd, Russia). It is resistant to attack by brown rust and Smut (fungus); medium-sensitive to powdery mildew; high drought resistant, winter hardiness is above the average level.

The plants were taken at the booting stage.

\section{Soils and climatic conditions}

The southern chernozem (by WRB classification Haplic Chernozem, Loamic, Aric (IUSS Working Group WRB. 2006)) of Crimean Steppe Zone is weaklyhumify. It is developed on Quaternary yellowish-brown loess-like light clays. The thickness of the humus layer (horizon A) is $24-36 \mathrm{~cm}$, totally $57-70 \mathrm{~cm}$. The humus content in the plow horizon is $2.4-2.7 \%$. $100 \mathrm{~g}$ of dry soil from plow layer contain $5.2 \mathrm{mg}$ of easily hydrolyzable nitrogen, $1.0-2.5 \mathrm{mg}$ of $\mathrm{P}_{2} \mathrm{O}_{5}, 42 \mathrm{mg}$ of $\mathrm{K}_{2} \mathrm{O}$. The total nitrogen is $0.11-0.12 \%$, phosphorus $-0.20 \%$, potassium $-1.96 \%$. The mechanical composition of the soil is slightly clayey. The structure is lumpy, dusty-powdery. The volumetric mass of a meter layer of soil is $1.24 \mathrm{~g} \mathrm{~cm}^{-3}$ 
Maximum hygroscopicity is $8.9 \%$. Wilting humidity is $11.5 \%$ of dry soil, or $47.3 \%$ of the lowest field capacity (LFC). LFC in meter layer of soil - $23,8 \%$ of dry soil. The reaction of the soil solution in the upper horizon is slightly alkaline $(\mathrm{pH}$ 7.7-7.9).

The climate of the Steppe is arid (Hydrothermal coefficient (HTC) - 0,7), moderately hot with moderately mild winter (Pashtetsky, 2015). The average annual air temperature is $9.7-10.5^{\circ} \mathrm{C}$. In July, at noon, the temperature rises up to 28.9-30. $2{ }^{\circ} \mathrm{C}$, and in some years to $40-42{ }^{\circ} \mathrm{C}$. The average minimum annual temperatures $-19-23{ }^{\circ} \mathrm{C}$. In winter the temperature can decrease to $31{ }^{\circ} \mathrm{C}$ below zero. Vegetation thaw is possible in $35 \%$ of winters. The period without frosts is 171 days. The sum of temperatures above $+10^{\circ} \mathrm{C}$ is $3280{ }^{\circ} \mathrm{C}$. The annual precipitation is $435 \mathrm{~mm}$. During the active vegetation period falls $285 \mathrm{~mm}$. The annual volatility is $843 \mathrm{~mm}$. The eastern (22\%) and northeastern (20\%) winds predominate. Strong winds are 28-30 days per year. The number of days with dry winds is $10-19$. The probability of droughts for most of the territory is $40-50 \%$ of years.

\section{Quantification of rhizosphere microorganisms}

Quantity of soil microorganisms of the main ecological-trophic groups (ammonifying and amylolytic bacteria, nitrogen fixing bacteria, micromycetes, cellulosolytics, actinomycetes, oligotrophs and pedotrophs) in winter wheat rhizosphere was determined according to conventional methods (Tepper $\boldsymbol{e t}$ al., 2005; Volkohon et al., 2010). It is shown in colony-forming units (CFU) per g of dry soil. The results were processed by statistical methods (Dospekhov, 1985).

\section{Isolation of new strains of microorganisms.}

To speed up the breeding process, the methodical approach has been used. It allows to conduct general selection of associative microorganisms for specific plant species (Sherstoboev and Melnichuk, 2005). The use of the Leonard system of vessels for growing plants provides obtaining the apical part of the root, which is free from substrate. This part of the root is populated by those microorganisms that independently or in cooperation with others are able to associate with the root system of a given plant species. And, since microorganisms and plants are in interaction and mutually influence each other the conditions of a cumulative culture of microorganisms with the selective influence of root exudates are created.

\section{Identification of new strains of microorganisms}

The DNA of new isolated strains of microorganisms was isolated from diurnal colonies. Gene JET Genomic Purification Kit (Thermofisher Scientific, Carlsbad, California, USA) was used to isolate genomic DNA according to protocols for gram-positive and gram-negative bacteria, respectively. Primers were applied to $16 \mathrm{~S}$ rRNA fD1/rD1 (AGA GTT TGA TCC TGG CTC AG/AAG GAG GTG ATC CAG CC) to identify the bacteria (Weisburg et al., 1991). PCR was carried out in the Hybaid Omn-E (Ashford, UK) in the following mode: initial denaturation at $95{ }^{\circ} \mathrm{C}$ for 2 minutes, 35 cycles, $94{ }^{\circ} \mathrm{C}$ for 30 seconds, $55^{\circ} \mathrm{C}$ for 30 seconds, $72{ }^{\circ} \mathrm{C}$ for $1 \mathrm{~min}$, the final synthesis $-72{ }^{\circ} \mathrm{C}-5 \mathrm{~min}$. Taq DNA Polymerase (recombinant) (Thermo Scientific, Vilnius, Lithuania) was used. For purification, the resulting products were transferred to a $1 \%$ agarose gel and electrophoresed in $0.5 \mathrm{x}$ TAE buffer. Purified amplicon was isolated from the targeted gel bands using the Cleanup Standart kit (Evrogen, Moscow, Russia). Sequencing was performed on Genetic Analyzer 3500 (Applied Biosystems, Waltham, Massachusetts, USA). The comparison of the obtained sequences was carried out in the NCBI database using the BLAST.n resource.

\section{RESULTS AND DISCUSSION}

\section{Quantity of rhizosphere ecologycal-trophic groups of microorganisms}

Among plant factors influencing the diversity of microbial communities of the rhizosphere, both plant species and variety are distinguished. Significant influence of the genotype on the formation of bacterial communities of the rhizosphere is shown on the example of barley (Bulgarelli et al., 2015) and rice (Edwards et al., 2015). Donn et al. (2015) have shown that changes in the qualitative and quantitative composition of rhizosphere bacteria of wheat depend on its genotype and plant age.

The microbiological analysis of the southern chernozem of the rhizosphere of the studied T. aestivum varieties showed quantitative differences in the composition of different ecological-trophic groups. In the rhizosphere of the Ermak variety, the number of microorganisms in most of the studied groups exceeded those of other varieties. Thus, the number of microorganisms that transform primarily organic nitrogen compounds (ammonifying agents) in the rhizosphere of this variety was 2.3 and 1.3 times higher than in Bagheera and Lydia, respectively, and the number of oligotrophs exceeded those for Bagheera and Lydia twice (Tab 1). The amount of amylolytic microorganisms in the rhizosphere of the Ermak grade also exceeded 2.8 and 1.4 times the indices of the varieties Bagheera and Lydia, respectively.

Table 1 Number of microorganisms of soft wheat rhizosphere, $10^{6} \mathrm{CFU} / \mathrm{g}$ of soil

\begin{tabular}{lllll} 
Variety & Ammonifiers & Amylolytics & Aligotrophs & Pedotrophs \\
\hline Bagheera & $5,0 \pm 0,3$ & $4,5 \pm 0,3$ & $1,5 \pm 0,2$ & $4,3 \pm 0,4$ \\
\hline Lydia & $8,8 \pm 0,4$ & $9,1 \pm 0,5$ & $1,9 \pm 0,4$ & $8,5 \pm 0,3$ \\
\hline Ermak & $11,5 \pm 0,4$ & $12,6 \pm 0,7$ & $4,0 \pm 0,3$ & $8,1 \pm 0,3$ \\
\hline
\end{tabular}

Variety Lydia took the leading positions in the number of Azotobacter and cellulolytic microorganisms. Excess in comparison with varieties Bagheera and Ermak was 7.9 and 2.9 times and 2.1 and 5.0 times, respectively (Fig 1 and Tab 2).

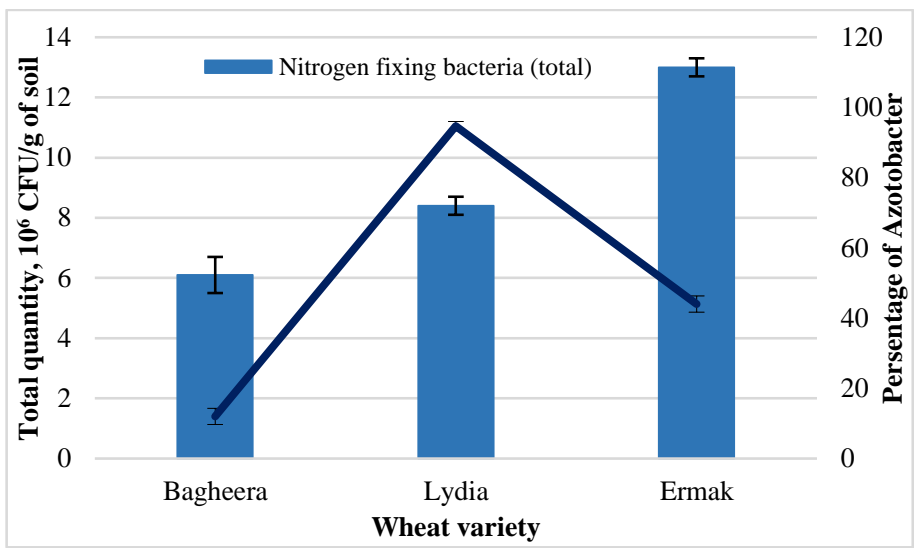

Figure 1 Number of nitrogen-fixing microorganisms of the soft wheat rhizosphere depending on the variety.

Table 2 Number of microorganisms of the soft wheat rhizosphere depending on the variety, $10^{3} \mathrm{CFU} / \mathrm{g}$ of soil

\begin{tabular}{lccc}
\hline Variety & Actinomycetes & Micromycetes & Cellulosolytics \\
\hline Bagheera & $0,5 \pm 0,0$ & $21,7 \pm 1,5$ & $13,8 \pm 3,3$ \\
\hline Lydia & $0,5 \pm 0,1$ & $29,2 \pm 3,0$ & $40,0 \pm 6,6$ \\
\hline Ermak & $0,8 \pm 0,1$ & $49,6 \pm 1,4$ & $8,0 \pm 0,4$ \\
\hline
\end{tabular}

\section{Isolation and identification of new strains of microorganisms}

From the apical part of the root of soft winter wheat variety Bagheera, nine morphotypes of microorganisms grown on southern chernozems of the steppe zone of the Crimea has been identified. The frequency of morphotypes occurrence varied from 17 to $100 \%$ and their abundance - from 0.1 to $31 \%$. Fourteen morphotypes with the same frequency range and an abundance within 0.3-33\% were isolated from the Ermak variety. It should be noted that the number of associative bacteria for this variety was maximum, as well as the quantity of rhizosphere microorganisms. The minimum number of morphotypes was isolated from the apical part of the wheat root of the Lydia variety. Five morphotypes had both high frequency of occurrence (83-100\%) and abundance (10-35\%).

The 16S rRNA gene of predominated in the apical part of the wheat roots bacteria morphotypes were sequenced. Five new isolated strains belonged to five species from various phyla and classes (Tab 3). Various kinds of plant growth promoting bacteria are reported, some of them are as follow: Flavobacterium Acetobacter, Pseudomonas, Azospirillum, Azotobacter, Arthrobacter, Micrococus, Chromobacterium, Agrobacterium, Bacillus, Burkholderia, Erwinia, Hypomycrobium, Xanthomonas, Klebsiella (Haghighi et al., 2011). This is confirmed by our study by the presence of 5 genera from previous list. 
Table 3 Identification of strains from the apical part of the roots of wheat

\begin{tabular}{|c|c|c|c|c|}
\hline Strains & $\begin{array}{l}\text { Nearest homologue } \\
\text { in GenBank NCBI }\end{array}$ & Homology, \% & Class & Phylum \\
\hline $\begin{array}{l}\text { Paenarthrobacter nitroguajacolicus M3 } \\
\text { [MH443746] }\end{array}$ & $\begin{array}{l}\text { Paenarthrobacter nitroguajacolicus } \\
\text { [ KY292435.1] }\end{array}$ & 99 & Actinobacteria & Actinobacteria \\
\hline $\begin{array}{l}\text { Bacillus sp. B5 } \\
\text { [MH443749] }\end{array}$ & $\begin{array}{l}\text { Bacillus thuringiensis } \\
\text { [KY316414.1] }\end{array}$ & 99 & Bacilli & Firmicutes \\
\hline $\begin{array}{l}\text { Agrobacterium tumefaciens } \mathrm{R} 1 \\
\text { [MH443751] }\end{array}$ & $\begin{array}{l}\text { Agrobacterium } \\
\text { [LT899998.1] }\end{array}$ & 99 & & \\
\hline $\begin{array}{l}\text { Sinorhizobium meliloti B2 } \\
\text { [MH443743] }\end{array}$ & $\begin{array}{l}\text { Sinorhizobium meliloti } \\
\text { [KU753918.1] }\end{array}$ & 99 & - $\alpha$-proteobacteria & Proteobacteria \\
\hline $\begin{array}{l}\text { Pseudomonas koreensis } \mathrm{V} 4 \\
\text { [MH443744] }\end{array}$ & $\begin{array}{l}\text { Pseudomonas koreensis } \\
\text { [CP014947.1] }\end{array}$ & 99 & $\gamma$-proteobacteria & \\
\hline
\end{tabular}

\section{Effectiveness of the new strains of selected microorganisms}

The study of the effect of isolated bacteria on the seed quality of wheat showed that certain strains (V4 and B2) provided an increase in the energy of germination for Bagheera seeds and improves germination by $5.3 \%$ (Fig 2). The reaction of varieties to inoculation with strains was different. This is shown in the development of wheat sprouts. Thus, Bagheera variety was the most responsive; depending on the strain, the biomass was increased by $0.9-0.19 \mathrm{~g}$ for shoots and by $0.03-0.1 \mathrm{~g}$ for root (Fig 3).

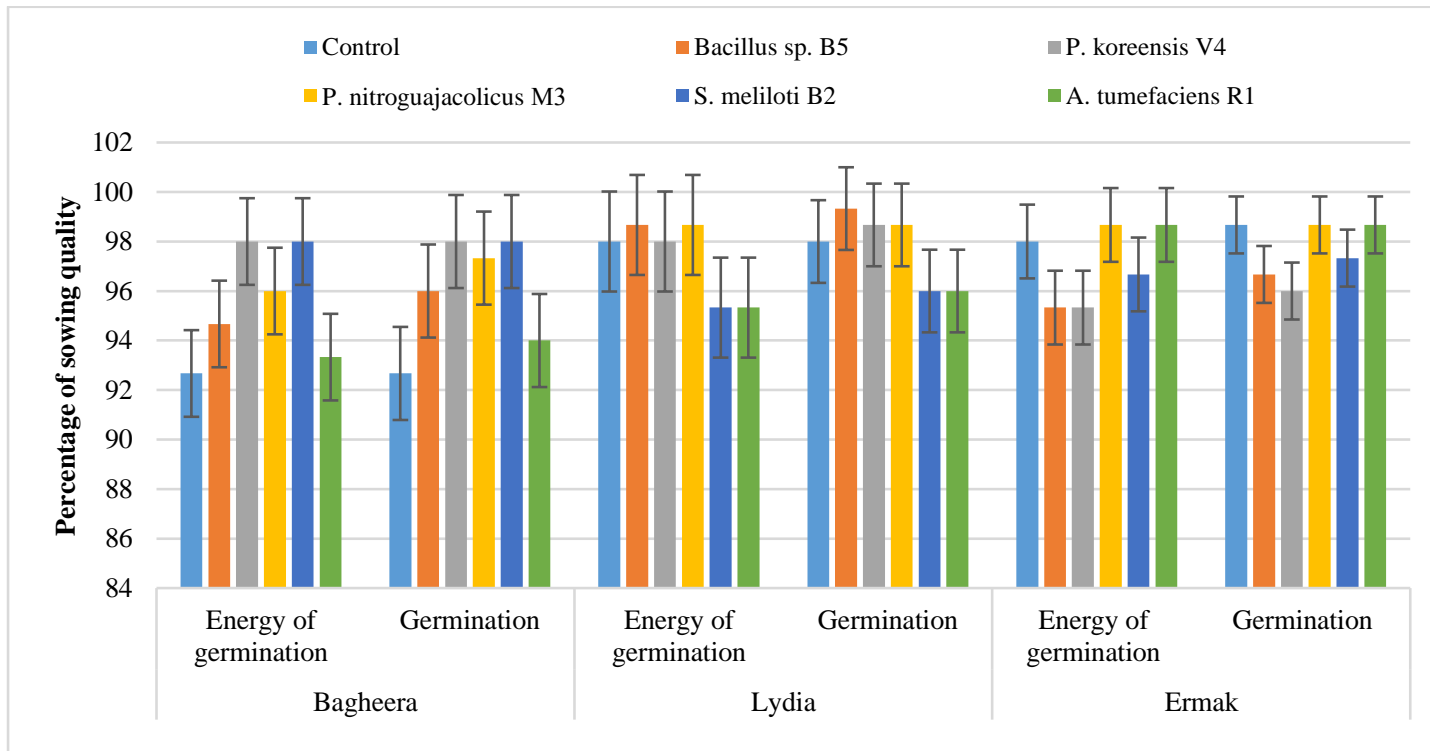

Figure 2 Influence of new strains of microorganisms on sowing quality of T. aestivum seeds.

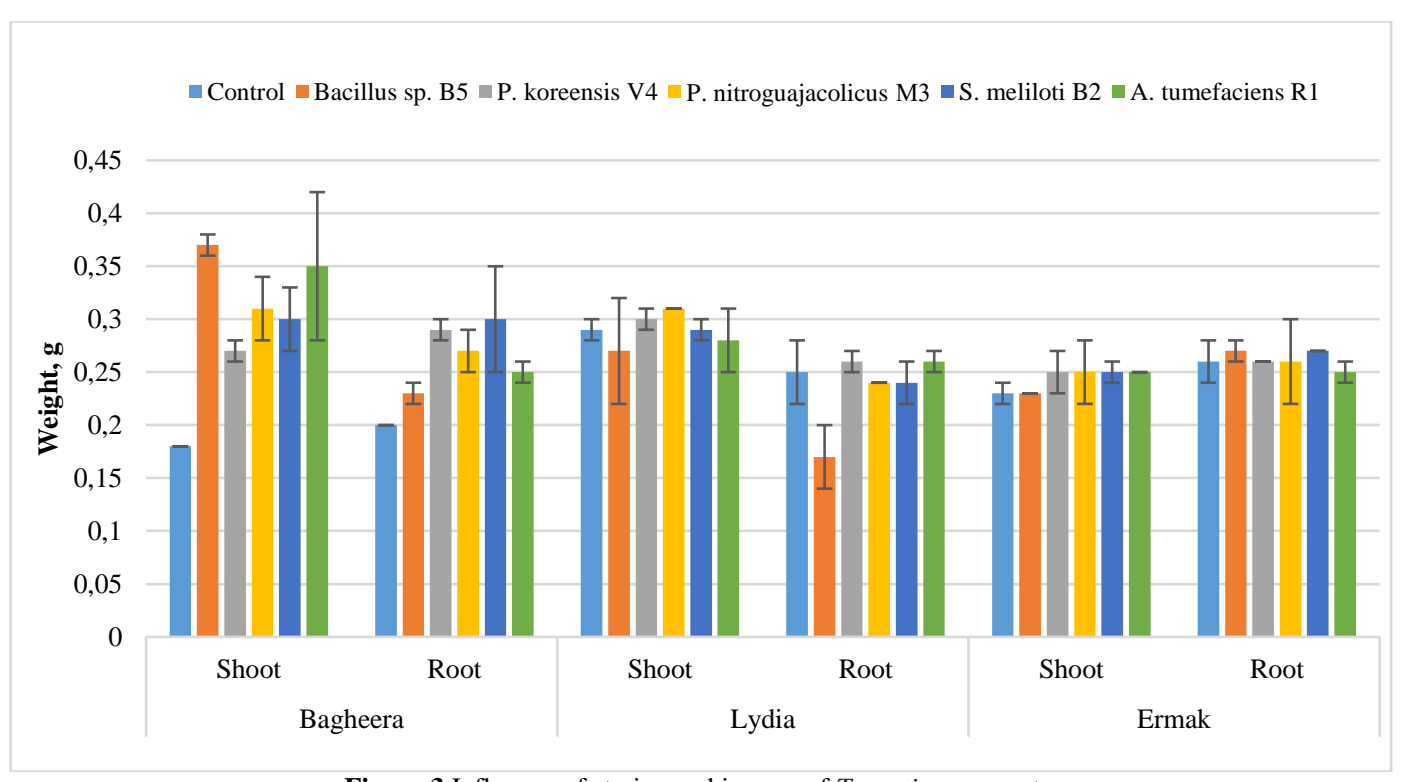

Figure 3 Influence of strains on biomass of T. aestivum sprouts.

\section{CONCLUSION}

Microbial community of the southern chernozem of three varieties $T$. aestivum rhizosphere was studied. Five associative bacteria strains were selected from the T. aestivum roots. There are Sinorhizobium meliloti; Pseudomonas koreensis Paenarthrobacter nitroguajacolicus; Bacillus sp. and Agrobacterium tumefaciens. They are increase the seed quality of the studied wheat varieties by
$5 \%$ and the biomass of the seedlings by $80 \%$. New strains are promising for further rhizosphere biotechnology in the agrocenosis.

Acknowledgements: The work was carried out within the Framework of the State Assignment of Fundamental Research No. 0834-2015-0005 and with the support of the RFBR grant A18-016-00197. 


\section{REFERENCES}

ARTAMONOVA,

MN

POTATURKIN-NESTEROV

N.I.,

BEZZUBENKOVA, O.E. 2014. The role of bacterial symbionts in plantmicrobial associations. Bulletin of Bashkir University, 19 (1).

BULGARELLI, D., GARRIDO-OTER, R., MÜNCH, P. C., WEIMAN, A. DRÖGE, J., PAN, Y., SCHULZE-LEFERT, P. 2015. Structure and function of the bacterial root microbiota in wild and domesticated barley. Cell host \& microbe, 17(3), 392-403. http://dx.doi.org/10.1016/j.chom.2015.01.011.

CARVALHO, T.L.G., BALSEMÃO-PIRES, E., SARAIVA, R.M., FERREIRA P.C.G., HEMERLY, A.S. 2014. Nitrogen signalling in plant interactions with associative and endophytic diazotrophic bacteria. Journal of experimental botany, 65(19), 5631-5642. http://dx.doi.org/10.1093/jxb/eru319.

DAL CORTIVO, C., BARION, G., VISIOLI, G., MATTAROZZI, M., MOSCA G., VAMERALI, T. 2017. Increased root growth and nitrogen accumulation in common wheat following PGPR inoculation: Assessment of plant-microbe interactions by ESEM. Agriculture, Ecosystems \& Environment, 247, 396-408. http://dx.doi.org/10.1016/j.agee.2017.07.006.

DONN, S., KIRKEGAARD, J. A., PERERA, G., RICHARDSON, A. E., WATT, M. 2015. Evolution of bacterial communities in the wheat crop rhizosphere. Environmental microbiology, 17(3), 610-621. http://dx.doi.org/10.1111/1462 2920.12452.

DOSPEKHOV, B.A. 1985. Methodology of field experience with the basics of statistical processing of research results (vol. 351). Moscow: Agroproizdat. 336

EDWARDS, J., JOHNSON, C., SANTOS-MEDELLÍN, C., LURIE, E., PODISHETTY, N.K., BHATNAGAR, S., SUNDARESAN, V. 2015. Structure variation, and assembly of the root-associated microbiomes of rice. Proceedings of the National Academy of Sciences, 112(8), E911-E920. http://dx.doi.org/10.1073/pnas.1414592112.

HAGHIGHI, B.J., ALIZADEH, O., FIROOZABADI, A.H. 2011. The role of Plant Growth Promoting Rhizobacteria (PGPR) in sustainable Agriculture Advances in Environmental Biology, 5(10), 3079-3083.

HUANG, X.F., CHAPARRO, J.M., REARDON, K.F., ZHANG, R., SHEN, Q., VIVANCO, J.M. 2014. Rhizosphere interactions: root exudates, microbes, and microbial communities. Botany, 92(4), 267-275. http://dx.doi.org/10.1139/cjb2013-0225.

IUSS WORKING GROUP WRB. 2006. World reference base for soil resources 2006. World Soil Resources Reports No. 103. FAO, Rome.

JHA, P. N., GUPTA, G., JHA, P \& MEHROTRA, R. 2013. Association of rhizospheric/endophytic bacteria with plants: a potential gateway to sustainable agriculture. Greener Journal of Agricultural Sciences, 3(2), 73-84.

LEBEDEV, V.N. 2014. Associative strains of bacteria as a modern element of greening cabbage plants. Izvestiya of the Russian State Pedagogical University A.I. Herzen, 168, 49-53

PASHTETSKY, V.S. 2015. Scientific bases of optimization of agrolandscapes and effective agrarian production of the Republic of Crimea (vol. 276) Simferopol: Arial. 273 c. ISBN 978-5-906813-87-9

SHAPOSHNIKOV, A.I., BELIMOV, A.A., KRAVCHENKO, L.V., VIVANKO D.M. 2011. Interaction of rhizosphere bacteria with plants: mechanisms of formation and factors of effectiveness of associative symbioses. Agricultural Biology, 3, 16-22.

SHERSTOBOEV, N.K. MELNICHUK, T.N. 2005. Methodological approach to the study of associative microorganisms. Bulletin of the Odessa National University. 10 (7). 311-315.

SINGH, R. P., JHA, P. N. 2016. The multifarious PGPR Serratia marcescens CDP-13 augments induced systemic resistance and enhanced salinity tolerance of wheat (Triticum aestivum $\quad$ L.). PLos one, 11(6), e0155026. http://dx.doi.org/10.1371/journal.pone.0155026.

SIVASAKTHI, S., USHARANI, G., SARANRAJ, P. 2014. Biocontrol potentiality of plant growth promoting bacteria (PGPR)-Pseudomonas fluorescens and Bacillus subtilis: A review. African Journal of Agricultural Research, 9(16), 1265-1277. http://dx.doi.org/10.5897/AJAR2013.7914.

SOUZA, R. D., AMBROSINI, A., PASSAGLIA, L. M. 2015. Plant growthpromoting bacteria as inoculants in agricultural soils. Genetics and molecular biology, 38(4), 401-419. http://dx.doi.org/10.1590/S1415-475738420150053.

TEPPER, E.Z. SHILNIKOVA, V.K., PEREVERZEVA, G.I. 2005. Workshop on microbiology. Moscow: Drofa. $445 \mathrm{p}$

VOLKOHON, V.V., NADKERNICHNA, O.V., TOKMAKOVA, L.M., MELNICHUK, T.M., CHAYKOVSKA, L.O., NADKERNICHNIY, S.P., SHERSTOBOEV, M.K., KOZAR, S.F., KOPILOV, E.P., KRUTILO, D.V., PARKHOMENKO, T.Y., KAMENEVA, I.A., ADAMCHUK-CHALA, N.I., KOVALEVSKA, T.M., DIDOVICH, S.V., VOLKOHON, K.I., PISCHUR, I.M. VOLKOHON, M.V., DIMOVA, S.B., KOMOK, M.S. 2010. Experimental soi microbiology:monograph. Kiev: Agrarian science. 464 p. ISBN 978-966-540$300-5$

WEISBURG, W.G., BARNS, S.M., PELLETIER, D.A., LANE, D.J. 1991. 16S ribosomal DNA amplification for phylogenetic study. J. Bacteriol. 173(2). 697 703.
YADAV, A.N., VERMA, P., SINGH, B., CHAUHAN, V.S., SUMAN, A. SAXENA, A.K. 2017. Plant growth promoting bacteria: biodiversity and multifunctional attributes for sustainable agriculture. Adv Biotechnol Microbiol, 5(5), 1-16. http://dx.doi.org/10.19080/aibm.2017.05.5556671. 